\title{
Advert Exposure on Consumer Purchase Decisions: An Empirical Study on MTN Nigeria
}

\author{
Aka Deborah ${ }^{1}$, Okorie Nelson $^{2}$ and Kehinde Joseph ${ }^{3}$ \\ ${ }^{1,3}$ Department of Business Management, School of Business, Covenant University, Ota, Ogun State \\ ${ }^{2}$ Departments of Mass Communication, School of Human Resource Development, Covenant University, \\ Ota, Ogun State
}

Correspondence should be addressed to: Aka Deborah; oluwaseunaka@yahoo.com

Received date: 15 September 2014; Accepted date: 10 December 2014; Published date: 2 September 2015

Academic Editor: Kalaivany Natarajan

Copyright (C) 2015. Aka Deborah, Okorie Nelson and Kehinde Joseph. Distributed under Creative Commons CC-BY 4.0

\begin{abstract}
This study investigated the effect of advertising on consumer purchase decision using MTN as an example. The specific objectives of the study were to: (i) Establish the relationship between advert exposure and customers' patronage of MTN services; (ii) Find out whether exposure to MTN advert has any effects on consumer awareness of such products and services; (iii) Examine the relationship between MTN's advert exposure and consumers' preference for MTN services competing brands, among others. The study used survey research method with three hypotheses. Based on the nature of the hypotheses, the study used correlation and Analysis of Variance (ANOVA) test Statistics to test the hypotheses. The Results showed that $\left(r=0.425^{* *}\right)$ between advert exposure and consumers' patronage of MTN products and services is significant and positive at the 0.05 level, the correlation $\left(r=0.373^{*}\right)$ between advert exposure and consumers preference for MTN service is moderately significant and positive at the 0.05 level, among others. The study recommends that advertising strategies be properly managed and maintained in getting attention through colourful and captivating advertisements. It also recommends that companies should invest in the use of advertisements for quality services. Moreover, adverts should be more customer-friendly; it should be simple for target audience to understand.
\end{abstract}

Keywords: advertising, exposure, consumer decision, patronage and MTN Nigeria

\section{Introduction}

Advertising is seen as a potent vehicle for achieving acceptance of desirable and useful concepts or ideas where the profit motive is minimal or missing altogether. Okorie (2009) reasoned that advertising has become an integral part of our social and economic system; it is indeed a powerful communication tool of business to most firms and organizations for them to be able to reach their target market across the globe. In other

Cite this Article as: Aka Deborah, Okorie Nelson and Kehinde Joseph (2015), "Advert Exposure on Consumer Purchase Decisions: An Empirical Study on MTN Nigeria", Journal of Accounting and Auditing: Research \& Practice, Vol. 2015 (2015), Article ID 435369, DOI: 10.5171/2015.435369 
words, advertising can be seen as a form of communication intended to persuade an audience (viewers, readers or listeners) to purchase or take some action upon products, ideals, or services.

Advertising can also serve to communicate an idea to a large number of people in an attempt to convince them to take a certain action (Bovee \& Aren, 1992; Jefkins, 1998; White, 2000; Okorie, 2010). In marketing management, advertising is one of the promotional tools used in creating and building brands in the business world.

Okorie and Aderogba (2011) observed that successful advertising is aimed at persuading consumers to engage in a specific action of purchase. Hence, advertising is a potent marketing approach used to attracting individuals to a brand in the market place. Among marketing scholars and scientists, the concept of purchase decisions is usually interlinked with the buyer's behaviour. This is because it is difficult or impossible to separate the psychological aspects of a consumer from purchase decisions. It is at this junction that advertising becomes an invaluable support for promoting goods and services.

The emergence of Global System of Mobile Communications (GSM) in 2001 in Nigeria has revolutionized the telecommunication sector in the Nigerian society. Today, the telecommunication industry in Nigeria has become a very competitive market with various service providers like Zain, Starcomms, Etisalat, Globacom, MTN-NG, Multi-links, etc; thus, there is a need for the use of advertising to create awareness and to promote the sales of that particular product or service.

There are several ad messages in the print media, but the issue is "do all these advert influence the consumers purchase decisions?" If advertisement does not create any positive change in consumers' purchase decisions, all the resources such as mission, money, message, media, and measurements will become ineffective. Therefore, it is important to find out to what extent advertisement influences a consumer in purchasing products and services in the telecommunication industry.

With the popularity of MTN in Nigeria, questions could be asked whether advertising influenced the patronage of services of MTN in Nigeria, or whether advertising significantly contributed to the brand equity of MTN. Some marketing scholars have argued that advertising has the power to influence potential buyers to patronize or purchase a product while some are of the opinion that advertising is not strong enough to influence potential buyers to patronize a product. Thus, this could be a research concern for scholars and social scientists, whether advertising could be seen as a tool of marketing to promote consumer purchase decisions. This study is out to evaluate the effect of advertising on consumer purchase decision using MTN as an example.

\section{Objectives of the Study}

The general objective of this study was to examine the effects of advertising on consumers' purchase decisions. The specific objectives of the study were to:

Establish the relationship between advert exposure and customers' patronage of MTN services.

Find out whether exposure to advert has any effects on consumer awareness of MTN services.

Examine the relationship between advert exposure and consumer's preference for MTN services among competing brands.

\section{Research Hypotheses}

Hypothesis according to Ojo (2005) is a testable proposition proffered by a researcher at the commencement of the research work which represents his beliefs and assumptions about the relationship that exists within the research variables. The following hypotheses were tested in this study.

\section{Hypothesis One}


$\mathrm{H}_{01}$ : There is no significant relationship between advert exposure and consumers' patronage of MTN products and services.

$\mathrm{Ha}_{1}$ : There is a significant relationship between advert exposure and consumers' patronage of MTN products and services.

\section{Hypothesis Two}

$\mathrm{H}_{02}$ : There is no significant effect of advert exposure on consumer awareness of MTN products and services.

$\mathrm{H}_{\mathrm{a} 2}$ : There is a significant effect of advert exposure on consumer awareness of MTN products and services.

\section{Hypothesis Three}

$\mathrm{H}_{03}$ : There is no significant relationship between advert exposure and consumers' preference for MTN services among competing brands.

$\mathrm{H}_{\mathrm{a} 3}$ : There is a significant relationship between advert exposure and consumers' preference for MTN services among competing brands.

\section{Advertising Effectiveness and Consumer Purchase Decisions}

It has been scientifically proven that advertisement affect consumers either positively or negatively. A positive effect will lead to sales and negative effect will lead to no sales. So we need to understand consumers and how they behave. A consumer is ordinarily looking for a product he can benefit from and this happens through the consumer decision making process. In the view of Lamb et al., (2003), "understanding how consumers make purchase decision can help marketing managers in several ways. When buying products a consumer generally follows the consumer decision making process".

The consumer decision process consists of five stages: need recognition, information search, evaluation of alternatives, purchase decision, and post-purchase behaviour
(Armstrong \& Kotler, 2007). Marketers need to focus on the entire buying process rather than just the purchase decision (Armstrong \& Kotler, 2007).

A consumer ordinarily is looking for a product that he can derive a benefit from. Behind the act of searching for this product and making a purchase lies a decision making process that must be investigated. Osuagwu (2002) opined that, there is a need for marketers to understand how buyers go through problem recognition, information search, evaluation of alternatives and purchase or post purchase behaviour processes.

A consumer usually passes through some stages or phases before making a purchase. These stages include: a)The Need Recognition b) Information Search c) Evaluation of Alternatives d) Purchase Decision e) PostPurchase Behaviour:

\section{Method of Study}

The survey method was used to achieve the objectives of the study. The survey method focuses on people, their belief, opinion, attitudes, motivation and behaviour. The survey research method is a common research method among social scientists (Kerlinger, 1973; 0jo, 2002; Sobowale, 2008), it is used to elicit responses among individuals in the society. According to Ojo (2005), survey is the type of research method that involves collecting data through asking people either in self administered copies of the questionnaire or through interviews. This method is appropriate because it was used to elicit responses from MTN subscribers on the influence of advertising on brand purchase. The survey method was adopted because the study has to do with a group of respondents that need to be asked some questions about advertising and how it has influenced their choice of using MTN lines.

The study population comprises of academic staff members of Covenant University and Crawford University. Thus, the study population comprises of 300 academic staffs 
in Covenant University and 100 academic staff in Crawford University. Any MTN subscriber within this population was eligible to be sampled.

The sample to be used in this study would be a sample size of 200, was derived out of a population of 400 with the use of Yard's formula for sample size determination and thus calculated as shown below;

The YARD's Formula:

$\mathrm{n}=$

$$
\frac{\mathrm{N}}{1+\mathrm{N}(\mathrm{e})^{2}}
$$

Where,

$\mathrm{n}=$ Sample size

$\mathrm{N}=$ Population

$\mathrm{e}=$ margin of error which is 0.05

Therefore, if these values are imputed into the formula, the sample size will be;

$$
\begin{aligned}
& \mathrm{n}=\frac{400}{1+400(0.05)^{2}} \\
& \mathrm{n}=\frac{400}{1+1} \\
& \mathrm{n}=\quad \underline{400}=200
\end{aligned}
$$

2

Therefore, from above the formula, the sample size is 200, made up of 150 MTN subscribers in Covenant University and 50 MTN subscribers in Crawford University. For the purpose of this research, the purposive sampling technique was used because the research is restricted to users or subscribers of MTN services. The sampling technique was used to select academic staff members who subscribe to MTN.

\section{Results}

The copies of the questionnaire were administered so as to collect the relevant data and to generate a valid conclusion. The population for the study was drawn from the Academic Staff of Covenant University and Crawford University in South West (Ogun State). This population consists of One hundred and fifty (126) academic staff in Covenant University and Fifty (46) Academics in Crawford University, who are consumers of MTN services.

Table 1: Response Rate

\begin{tabular}{|l|l|l|}
\hline Questionnaires & No. of Respondents & Response Rate (\%) \\
\hline Questionnaire Returned and used & 172 & 86 \\
\hline Questionnaire not returned & 28 & 14 \\
\hline Total & 200 & 100 \\
\hline
\end{tabular}

Source: Field Survey, 2012

A total of 200 copies of the questionnaire were administered to the academic staff of Covenant University and Crawford University, in Ogun State, South West Nigeria. From the table above, it is evident that 172 copies of the questionnaire representing

$86 \%$ were returned and used for the study, while 28 copies of the questionnaire representing $14 \%$ were not returned. The $86 \%$ copies of the questionnaire returned shows a reasonable level upon which the research can be based, comparing the number of questionnaires administered to the actual number returned.

\section{Test of Hypothesis}

Testing For Hypothesis One

$\mathrm{H}_{01}$ : There is no significant relationship between advert exposure and consumers' patronage of MTN services. 
Ha1: There is a significant relationship between advert exposure and consumers'

patronage of MTN services.

Table 2: Correlations

\begin{tabular}{|c|c|c|}
\hline & $\begin{array}{l}\text { Advert } \\
\text { influences your } \\
\text { decision to buy } \\
\text { or subscribe to } \\
\text { MTN Network. }\end{array}$ & $\begin{array}{l}\text { Adverts have } \\
\text { contributed } \\
\text { significantly to } \\
\text { your purchase } \\
\text { of MTN services }\end{array}$ \\
\hline $\begin{array}{l}\text { Advert influences } \text { yourPearson Correlation } \\
\text { decision to buy or subscribeSig. (2-tailed) } \\
\text { to MTN Network. }\end{array}$ & 1 & $\begin{array}{l}425^{* *} \\
.000 \\
172\end{array}$ \\
\hline $\begin{array}{l}\text { Adverts have contributedPearson Correlation } \\
\text { significantly to yourSig. (2-tailed) } \\
\text { purchase of MTN services } \mathrm{N}\end{array}$ & $\begin{array}{l}425^{* *} \\
.000 \\
172\end{array}$ & $\begin{array}{l}1 \\
172\end{array}$ \\
\hline
\end{tabular}

**. Correlation is significant at the 0.01 level (2-tailed).

Interpretation: The relationship between MTN advert exposure and consumers' patronage was investigated using Pearson's correlation coefficient. There was a positive correlation between the two variables. $(\mathrm{r}=$ $0.425^{* *}, \mathrm{n}=172, \mathrm{p}<0.05$ ).

Discussion of the result of hypothesis One: The implication of this result is that advertising could be used as a marketing tool to increase the demand of a product or service as well as the patronage of services.

\section{Testing For Hypotheses Two}

$\mathrm{H}_{02}$ : There is no significant effect of advert exposure on consumer awareness of MTN services.

$\mathrm{H}_{\mathrm{a} 2}$ : There is a significant effect of advert exposure on consumer awareness of MTN services

Table 3: Model Summary

\begin{tabular}{|l|l|l|l|l|l|}
\hline Model & $\mathbf{R}$ & R Square & $\begin{array}{l}\text { Adjusted } \\
\text { Square }\end{array}$ & $\begin{array}{l}\text { Rtd. Error of the } \\
\text { Estimate }\end{array}$ \\
\hline 1 & $326^{\mathrm{a}}$ & 106 & 101 & .93220 \\
\hline
\end{tabular}

Source: Field Survey, 2012

a. Predictors: (Constant), I am familiar with MTN services through advertisement

b. Dependent Variable: Awareness of MTN services

Interpretation of Result: The model summary table shows how much of the variance is used in the dependent variable (I have seen the
MTN advert aired on television, newspapers, billboards etc) is explained by the model. In this case, the R square is 0.106 , if expressed as a percentage is $11 \%$.

Table 4: ANOVA(b) 


\begin{tabular}{|ll|l|l|l|l|l|}
\hline Model & & Sum of Squares & df & Mean Square & F & Sig. \\
\hline 1 & Regression & 17.549 & 1 & 17.549 & 20.194 & $.000^{\text {a }}$ \\
& Residual & 147.730 & 170 & .869 & & \\
& Total & 165.279 & 171 & & & \\
\hline
\end{tabular}

Source: Field Survey, 2012

a. Predictors: (Constant), I am familiar with MTN services through advertisement.

b. Dependent Variable: Awareness of MTN services.

Interpretation of Result: The ANOVA table shows the assessment of the statistical significance of the result. The table tests the null hypothesis. We reject the null hypothesis if the $\mathrm{P}-$ value is $\leq 0.05$. From the above, the model in this table reaches statistical significance $(\operatorname{sig}=000)$, in which the $\mathrm{P}$ - value is equal to .000 , and less than or equal to 0.05 , therefore we reject the null hypothesis. So, we can conclude that one of the predicators is useful for predicting exposure of MTN services on media objective of the study.

Table 5: Coefficients (a)

\begin{tabular}{|c|c|c|c|c|c|c|}
\hline \multirow[b]{2}{*}{ Model } & & \multicolumn{2}{|c|}{ Unstandardized Coefficients } & \multirow{2}{*}{ 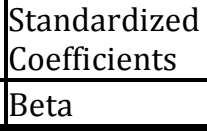 } & \multirow[b]{2}{*}{$\mathrm{T}$} & \multirow[b]{2}{*}{ Sig. } \\
\hline & & $B$ & Std. Error & & & \\
\hline & (Constant) & 2.736 & 333 & & 8.215 & .000 \\
\hline & $\begin{array}{lr}\text { I am familiar with MTN } \\
\text { services } \\
\text { advertisement }\end{array}$ & 374 & .083 & 326 & 4.494 & .000 \\
\hline
\end{tabular}

Source: Field Survey, 2012

\section{a. Dependent Variable: Awareness of MTN services}

Interpretation of Result: The table shows which variables were included in the model contributed to the prediction of the dependent variable. The study is interested in comparing the improvement of each independent variable; therefore, the Beta values used for the comparison in this table, the only beta coefficient is .326 which is for being familiar with MTN through advertisement. This means:
Test for Hypothesis Three

$\mathrm{H}_{03}$ : There is no significant relationship between MTN advert exposure and consumers' preference for MTN services among competing brands.

$\mathrm{H}_{\mathrm{a} 3}$ : There is a significant relationship between MTN advert exposure and consumers' preference for MTN services among competing brands.

\section{Discussion of Result}


IBIMA Publishing

Journal of Accounting and Auditing: Research \& Practice

http://www.ibimapublishing.com/journals/JAARP/jaarp.html

Vol. 2015 (2015), Article ID 435369, 9 pages

DOI: $10.5171 / 2015.435369$

Table 6 : Correlations

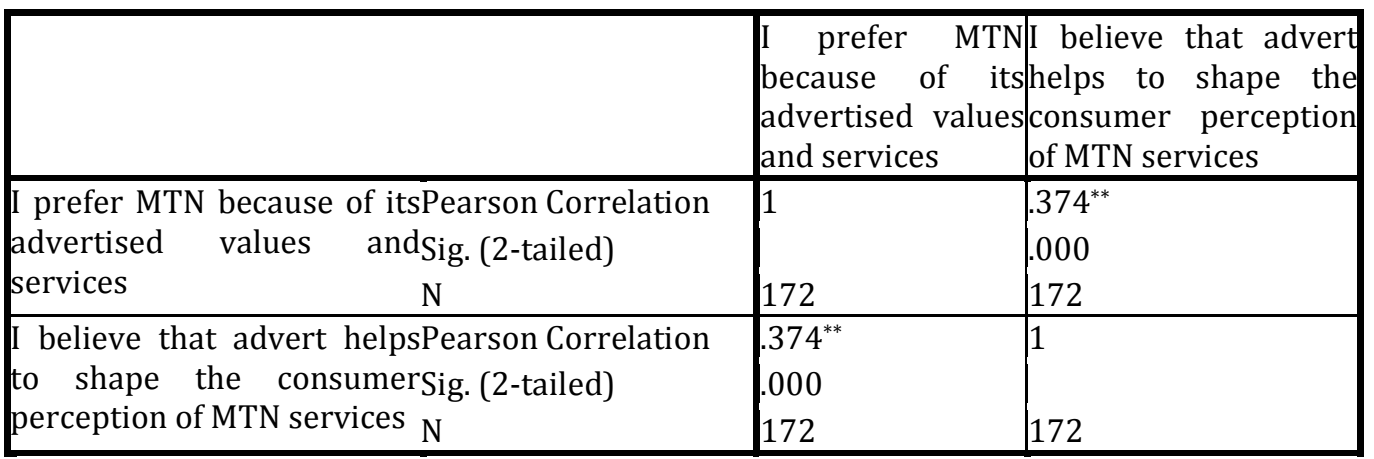

**. Correlation is significant at the 0.01 level (2-tailed).

Interpretation: The relationship between advert exposure and consumers preference for MTN services among competing brands was investigated using Pearson's correlation coefficient. There was a positive correlation between the two variables. $\left\{\mathrm{r}=0.373^{*}, \mathrm{n}=\right.$ $172, \mathrm{p}<0.05\}$

\section{Discussion of Findings}

For Hypothesis one, The correlation ( $\mathrm{r}=$ $0.425^{* *}$ ) between MTN advert exposure and consumers' patronage is significant and positive at the 0.05 level, thus we reject the null hypothesis $\left(\mathrm{H}_{01}\right)$ which says there is no significant relationship between MTN advert exposure and consumers' patronage of MTN services and accept the alternate hypothesis $\left(\mathrm{Ha}_{1}\right)$ which says there is a significant relationship between MTN advert exposure and consumers' patronage of MTN services.

For hypothesis two, the implication of this result is that advertising is essential in making the respondents familiar with the products or services. It has the power to make the consumer remember and retain messages of advertised products and services. This result is in line with the finding of Adeolu et al., (2005); they found out that advertising has a tremendous effect on the buying behavior.

For hypothesis three, The correlation $(\mathrm{r}=$ $0.373^{*}$ ) between advert exposure and consumers' preference for MTN service is moderately significant and positive at the 0.05 level, thus we reject the null hypothesis $\left(\mathrm{H}_{02}\right)$ which says there is no significant relationship between advert exposure and consumers' preference for MTN services, and accept the alternate hypothesis $\left(\mathrm{H}_{\mathrm{a} 2}\right)$ which says that there is a significant relationship between advert exposure and consumers' preference for MTN services among competing brands. The implication of this result is that advertising does not only have the power to make consumers remember and retain advertised messages, but also has the influence to make consumers prefer a particular product to other competing products. This result corroborates the findings of Vivekananthan (2010), they found out that advertisements can influence brand preference if the ad messages promote information, communication and comprehension

\section{Conclusion and Recommendations}

This study has demonstrated that there is a strong relationship between MTN's advert exposure and customers' patronage of MTN services. Thus, organisations can rely on the power of advertising to promote patronage. Interestingly, this study has found out that advert intensity has tremendous effects on the products' awareness in the eyes of consumers. Hence, exposure to advertising is key for product and brand awareness. One of the

Cite this Article as: Aka Deborah, Okorie Nelson and Kehinde Joseph (2015), "Advert Exposure on Consumer Purchase Decisions: An Empirical Study on MTN Nigeria", Journal of Accounting and Auditing: Research \& Practice, Vol. 2015 (2015), Article ID 435369, DOI: 10.5171/2015.435369 
major findings of this study reveals the relationship between MTN's advert exposure and consumers' preference for MTN services among competing brands. In essence, advertising is a marketing tool essential for brand equity management.

Also, this study determined that advert exposure can promote advertiser-customers relationship between MTN Nig. Ltd. and its teaming customers. In other words, advertising is essential for promoting advertiser-customers base.

This study, therefore, makes the following policy recommendations which company executives, users of the project and future researchers will find beneficial when implemented:

From this study, respondents noted that most telecommunication industries do not live up to their promises. It is suggested that services should be cost friendly to promote customer loyalty.

It is suggested that companies should invest more on technology so as to promote better services. In other words, companies should also increase their broadband and width so as to accommodate their ever increasing customer base. Companies should ensure that their services are technologically hitched free. Equipment should be upgraded to accommodate growth and expansion.

As matter of policy, the government should issue a directive as regards the type of advertisement used in communicating to customers in the Nigerian society. In essence, companies should invest in the use of advertisements for quality services.

It is also suggested that advertising strategies be properly managed and maintained in getting attention through colorful and captivating advertisements. Also, adverts should be more customer-friendly; they should be simple for a layman to understand.
As a matter of policy, the government should issue a directive as regards sustainable corporate social responsibility to their teaming customers. Companies should make sure that network service is always available across the segments of the Nigerian society.

\section{References}

1. Ayanwale, A. B, Alimi, T. \& Ayanbimipe, M. A. (2005). "The Influence of Advertising on Consumer Brand Preference". Journal of Social Science, 10 (1), 9-16.

2. Asika, N. (2009). Research Methodology in Behavioural Sciences: Lagos. Longman Publication

3. Bovee, S. (1992). Advertising. New York: McGraw - Hill publishing Company

Jefkins, F. (1998). Public Relations, Fifth ed. England: Pearson Education Ltd.

4. Joseph, D. (1999). The dynamics of mass communication. New York: McGraw-Hill companies.

5. Katke, K. (2007). The Impact of Television Advertising on Child Health \& Family Spending, International Marketing Conference on Marketing and Society.

6. Kotler, P. and Keller, K.L., (2007). A Framework for Marketing Management, $3^{\text {rd }}$ edition,

Pearson Prentice Hall, U. S. A.

7. Kotler, P. \& Armstrong, G. (2008). Principles of Marketing: Upper Saddle River, New Jersey: Pearson Prentice Hall, Inc.

8. Lamb, W. Hair, F.\& McDaniel, C.(2003).Marketing. Washington DC, USA: South Western

College

9. Ojo, O. (2005). Fundamentals of Research Methods. Lagos: Standard Publications Okorie, N. (2010). Celebrity advertising and its effect on brand loyalty. Interdisciplinary Journal of contemporary research in business. 
Canterbury: United Kingdom. Institute of nterdisciplinary Business Research. 1(4), 7088

10. Okorie, N and Adeyemi, A. (2011). The role of celebrity advertising on brand patronage.

International Journal of Research in Computer Application and Management, Haryana,

India. Retrievable at www.ijrcm.org.in. 1(1), 27-34.

11. Osuagwu, L. (2002). Marketing: Principles and Management, Lagos: Grey Resources Limited.
12. Pride, W.M. and Ferrell, O.C. (2000). Marketing. Houston: Houghton Mifflin Company.

13. Romaniuk, J. \& Sharp, B. (2004). Conceptualizing \& measuring brand salience. Marketing Theory Articles, 4(4), 327-342.

14. Sorina- Raula, G., Liviu, C., \& GeorgetaMadalina, M. (2012). The Role of Advertising In The

Purchase Decision Process. Retrieved December 12, 2012 from www. Steconomic.uoradea.ro on February 18, 2012. 